\title{
Philonotis calcarea (Bryophyta) in the Opole Province (Poland)
}

Adam Stebel

Philonotis calcarea (Bryophyta) in the Opole Province (Poland). - Acta Mus. Siles. Sci. Natur., 63: 65-68, 2014.

\begin{abstract}
Philonotis calcarea (Bruch \& Schimp.) Schimp. in Poland is a montane species, very rarely occurring in lowland, strictly protected by law. In the Opole Province till this time it has been known from four localities, reported from the 19th and first half of the 20th century. The paper presents description of the new locality and list of stations of $P$. calcarea in the Opole Province. Current distribution of this species is presented on the map.
\end{abstract}

Key words: mosses, threatened species, protected species, distributional data, excavation, Silesian Upland, Opole Province, Poland.

\section{Introduction}

Philonotis calcarea (Bruch \& Schimp.) Schimp. in Poland is strictly protected by law (Anonymus 2012), montane species confined to calcitrophic brown-moss fen communities from the class Scheuchzerio-Caricetea nigrae (especially Valeriano-Caricetum flavae association) and calcitrophic spring communities from the class Montio-Cardaminetea (mainly Cratoneuretum falcati association). In lowland it is very rare and known from scattered localities.

The Opole Province is the area with strongly changed environment what results in extinction or reduction of number of localities of many plants (e.g. Nowak, Spałek 2002). Philonotis calcarea has been known from this area from four localities, all of them originating from the 19th and first half of the 20th century. Despite intensive search they were not confirmed thus this species was placed in Red list of Opole Province in the category Ex (Stebel 2006a). In 2012 large population of this species was found in the 'Górażdże' limestone quarry located on Silesian Upland (Fig. 1).

\section{Description of the new locality}

The new locality was found 19 May 2012 in the abandoned part of the large limestone quarry excavation 'Górażdże' (Fig. 2) GPS coordinates are as follow: [N 50 $31^{\prime} 52.9^{\prime \prime}$; E $\left.18^{\circ} 02^{\prime} 43.8^{\prime \prime}\right]$. The population covers an area of several dozen square metres and occurs mainly on the bank of the drainage ditch (Fig. 3). It grows in compact turfs and many individuals profusely produce sporophytes. Some smaller subpopulations were found in the vicinity, growing on wet waysides and bare soil. This locality is not threatened by human activity, but could be by overgrown by shrub and forest communities.

\section{List of localities from the Opole Province}

On the area of the Opole Province Philonotis calcarea is known from 5 stations; 4 of them are considered as extinct (Fig. 4). List of localities is arranged according to the ATMOS grid square system (Ochyra \& Schmajda 1981).

Fc 15: Krapkowice (leg. Schulze 1885, WRSL, Berdowski, Koła 1981); between Krapkowice and Pietna (Torka 1931).

Fc 16: Górażdże, limestone quarry (leg. A. Stebel, 2012, SOSN).

Fc 23: near Biała (Torka 1931)

Fc 65: gypsum excavation near Kietrz (Milde 1860), gypsum excavation near Dzierżysław near Racibórz (Milde 1861, 1869). Information concern the same locality, at present place called Góra Gipsowa (= Gypsum hill) lying east of Dzierżysław and south of Kietrz. 


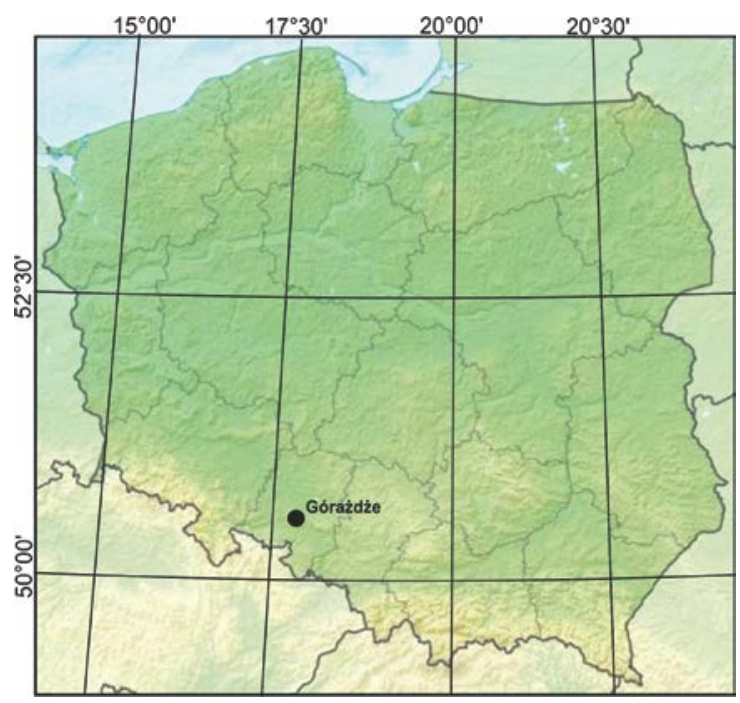

Fig 1: Location of investigated area in Poland.

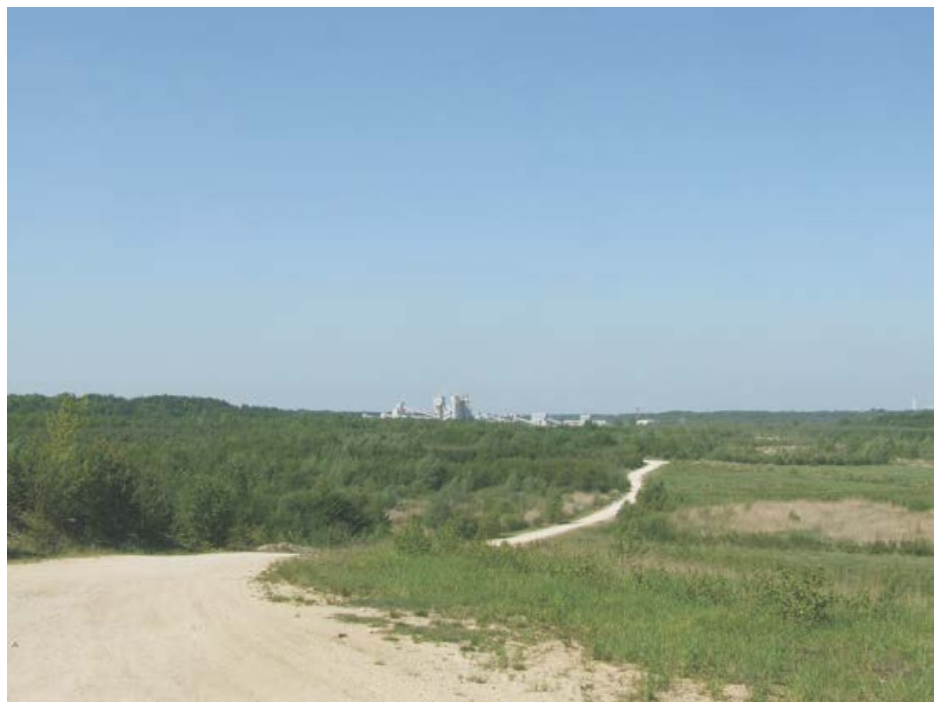

Fig 2: General view on the 'Górażdże' limestone quarry, near the road locality of Philonotis calcarea occurs (Photo by A. Stebel, 19 May 2012 )

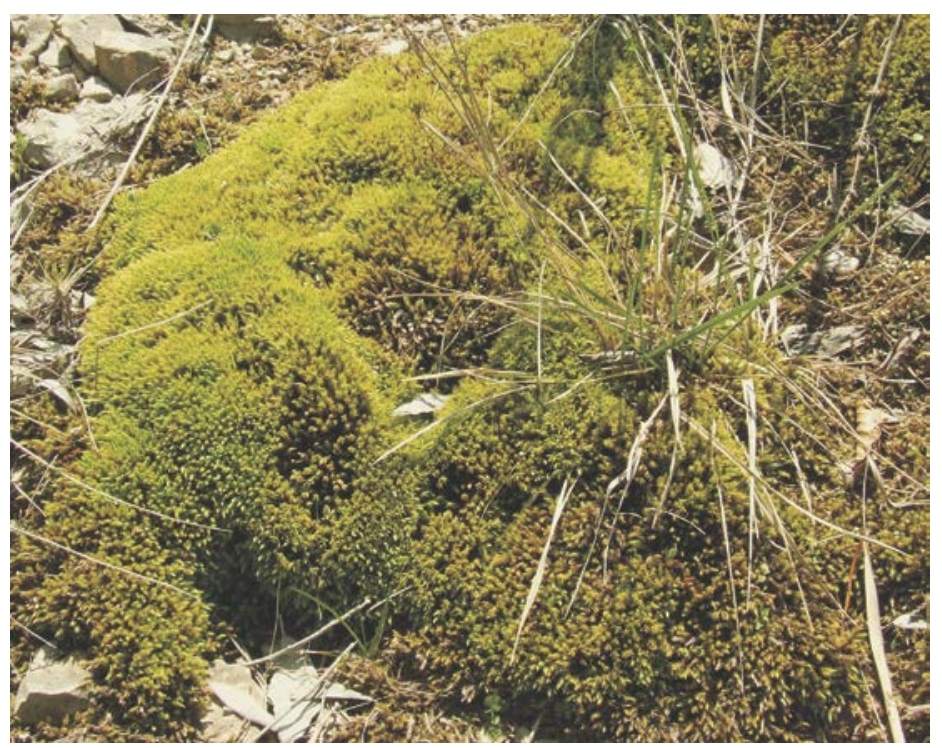

Fig 3: Turf of thick-nerve Apple moss Philonotis calcarea (Photo by A. Stebel, 19 May 2012 ) 


\section{Discussion}

Closed or abandoned excavations of mineral resources, often regarded as wasteland, are in many cases refuge of threatened and protected plants, fungi and animals. In Poland, for example, many rare bryophytes were reported from these habitats, for example Lophozia badensis (Stebel 1999, Stebel 2006b) and Discelium nudum (Stebel 1997). That is why they are worth special protection and shoud be thoroughly checked in terms of the presence of rare species.

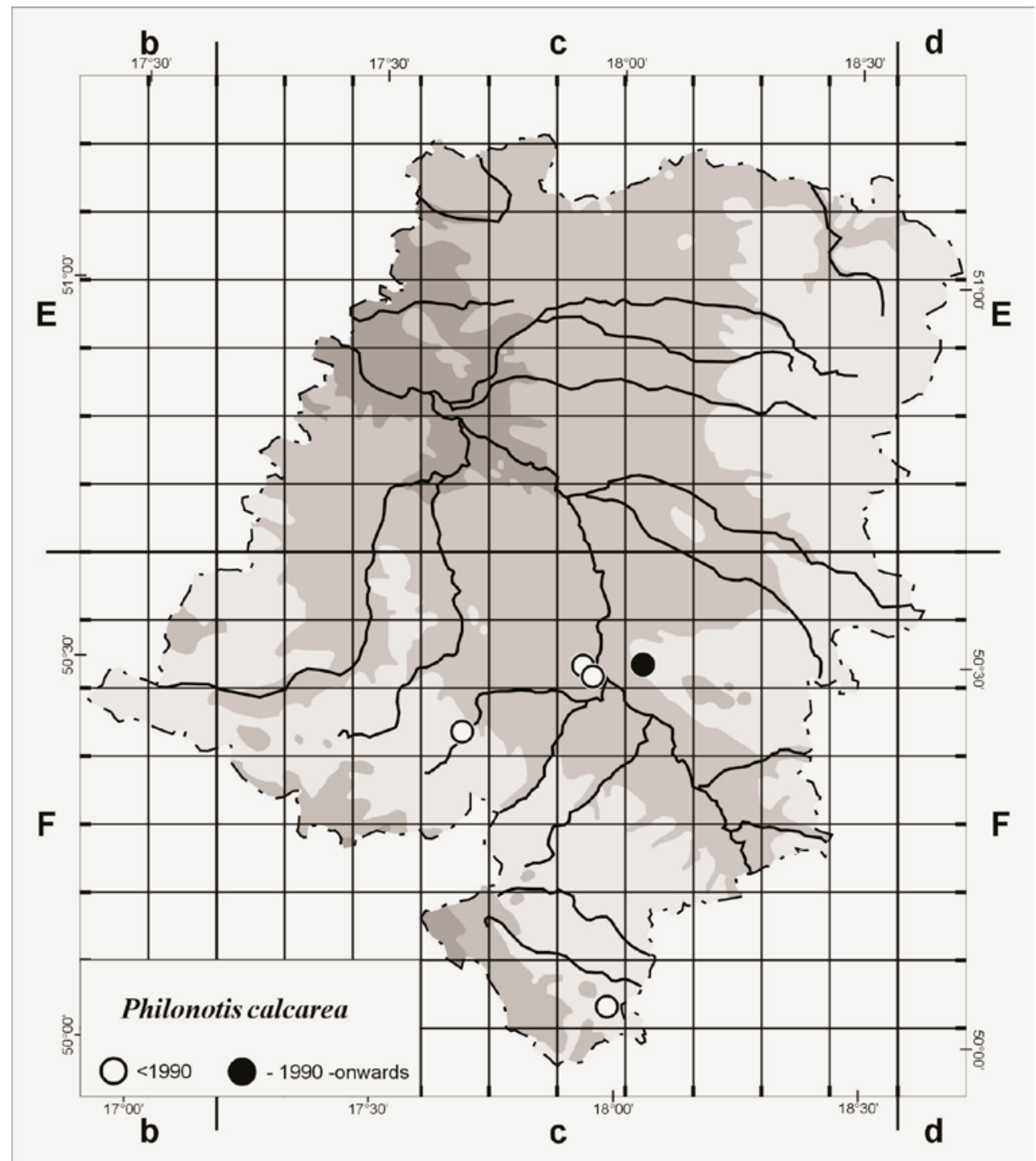

Fig 4: Current distribution of Philonotis calcarea in the Opole Province.

\section{References}

Anonymus (2012): Rozporządzenie Ministra Środowiska z 5 stycznia 2012 r. w sprawie ochrony gatunkowej roślin. Dziennik Ustaw Rzeczpospolitej Polskiej 0 (2012), 81.

Berdowski W.\& Koła W. (1981): Stan badań Opolszczyzny pod względem briologicznym. - Zeszyty Przyrodnicze Opolskiego Towarzystwa Przyjaciół Nnauk 20: 3-14.

Nowak A. \& Spałek K. (eds) (2002): Czerwona księga roślin województwa opolskiego. Rośliny naczyniowe wymarłe, zaginione i rzadkie. Śląskie Wydawnictwo ADAN, Opole, 158 pp.

Milde J. (1860): Mittheilungen über die schlesische Cryptogamen-Flora. - Jahresber. Schles. Ges. Vaterl. Cult., 37: 51-73. 
- (1861): Uebersicht über die schlesische Laubmoos-Flora. - Bot. Zeit. 19 Beil.: 1-48.

- (1869): Bryologia Silesiaca, Laubmoos-Flora von Nord- und Mittel-Deutschland, unter besonderer Berücksichtigung Schlesiens und mit Hinzunahame der Floren von Jütland, Holland, der Rheinpfalz, von Baden, Franken, Böhmen, Mähren und der Umgegend von München. Arthur Felix, Leipzig, 410 pp.

Ochyra R. \& Szmajda P. (1981): La cartographie bryologique en Pologne. In: J. Szweykowski (ed.), New perspectives in bryotaxonomy and bryogeography. Uniwersytet im. Adama Mickiewicza w Poznaniu Seria Biologia 20: 105-110.

Stebel A. (1997): W sprawie ochrony stanowiska osadniczka nagiego Discelium nudum na Wyżynie Śląskiej. Chrońmy Przyr. Ojcz. 53: 91-93.

- (1999): Lophozia badensis (Hepaticae, Lophoziaceae) in the Silesian Upland. - Fragm. Flor. Geobot. 44: 199201.

- (2006a): Red-list of bryophytes of Opole Province (Poland). - Nature Journal 39: 35-43.

- (2006b): New bryophyte data for mineral workings in Upper Silesia (Poland). In: A. Nowak \& G. Hebda (eds): Biodiversity of quarries and pits, Opole Scientific Society - 1rd Department of Natural Sciences, Opole-Górażdże, pp. 71-81.

Torka V. (1931): Die Moosflora von Oberschlesien. - Hedwigia 70: 157-210.

Author's address: Adam Stebel, Department of Pharmaceutical Botany, Medical University of Silesia in Katowice, ul. Ostrogórska 30, 41-200 Sosnowiec, Poland, e-mail: astebel@sum.edu.pl 